\title{
INSECTICIDAL EFFECTS ON SOME SOIL ORGANISMS
}

\author{
J. M. KeI.SEY \\ Entomology Division, Department of Scientific and Industrial \\ Research, Lincoln
}

\section{Summary}

The paper records effects of organochlorine and organophosphate insecticides on five macro-faunal groups of soil organisms, and discusses possible harmful effects on soil structure. It also records effects of some organophosphate insecticides well beyond their generally accepted short chemical life.

\section{INTRODUCTION}

REFERENCES to work on the value of the larger soil organisms in maintaining productivity of soils, and possible harmful side-effects of insecticides are given in a paper by Kelsey and Arlidge (1967), and effects on microfauna are discussed by Jones (1956), Meagher (1963), Wallace (1961) and '63) and Garretson and van Clemente (1968). This paper records the numbers of soil organisms in plots treated with organochlorine and organophosphate insecticides.

\section{METHODS}

Soil samples were taken from DSIR trials against pasture pests on plots measuring $1 / 2 \mathrm{ch} \times 1 / 2 \mathrm{ch}$ or $1 / 4 \mathrm{ch} \times 1 / 4 \mathrm{ch}$, and treatments were randomized within replicates after selecting areas most heavily infested by the common grass grub (Costelytra zealandica White). Two 3 in. diameter samples 3 in. deep were taken at random from each of three replicates at each count. Samples were wrapped separately in plastic bags to avoid moisture losses and organisms during transit to the laboratory where they were examined after cutting off the top $1 / 4$ in. of soil and trimming to a 3 in. depth, so that fauna in soil only was counted. The sample was then crumbled after adding water where necessary, and the whole sample was examined in fractions in shallow dishes under a $\times 60$ dissecting microscope. Definitions used for convenience in this paper are: "worms", which included all segmented worms, portions of earthworms of $1 / 2$ in. or more being counted as whole worms; "nematodes", which included only those readily seen at the magnifications used; "mites", which were in five groups - three of them predacious; and "collembola", which were those found only within the soil, and included five species. Insecticide dosages were at $2 \mathrm{lb}$ active ingredient (a.i.) per acre except for fensulfothion at $1 \mathrm{lb}$ a.i. at West Melton. Halkett treatments were applied in 1962, Timaru in 1965 , and West Melton in 1968. At Timaru and West Melton, where numbers of organisms recovered were low or nil, the significance is based on probability when differences for significance are not listed. Analyses were on the basis of transformed data on $\sqrt{ }(n+0.5)$. 


\section{RESULTS}

At Halkett the effects of insecticides in lowering numbers of organisms statistically were as follows:

\section{At 1 week after treatment:}

Worms: isobenzan and phorate at $0.1 \%$ level, carbaryl $1 \%$.

Nematodes: isobenzan and trichlorfon $5 \%$, diazinon $1 \%$, phorate $0.1 \%$.

Mites: dieldrin $5 \%$, heptachlor $1 \%$, isobenzan, diazinon, trichlorfon and and phorate all $0.1 \%$.

C. zealandica: dieldrin 5\%, carbaryl $1 \%$, DDT, isobenzan, diazinon and trichlorfon all $0.1 \%$

Collembola: dieldrin, diazinon, trichlorfon and carbaryl all $1 \%$, isobenzan and phorate $0.1 \%$.

At 13 weeks after treatment:

Worms: isobenzan $0.1 \%$.

Nematodes: isobenzan $5 \%$, dieldrin, heptachlor, diazinon, trichlorfon and phorate all $0.1 \%$.

Mites: heptachlor $1 \%$, isobenzan and phorate $0.1 \%$.

C. zealandica: DDT, dieldrin, diazinon and carbaryl all 1\%, heptachlor, isobenzan, trichlorfon and phorate all $0.1 \%$.

Collembola: diazinon and carbaryl $5 \%$, dieldrin, heptachlor and diazinon

$1 \%$, isobenzan and phorate $0.1 \%$.

At 52 weeks after treatment:

Worms: isobenzan $0.1 \%$

Nematodes: isobenzan $1 \%$, dieldrin and heptachlor $0.1 \%$.

Mites: dieldrin 5\%, heptachlor and isobenzan $0.1 \%$.

C. zealandica: DDT, dieldrin, heptachlor and isobenzan all $5 \%$.

Collembola: heptachlor $1 \%$, isobenzan $0.1 \%$.

At 104 weeks after treatment:

Worms: isobenzan $0.1 \%$.

Mites: heptachlor $1 \%$, isobenzan $0.1 \%$.

C. zealandica: DDT, dieldrin, heptachlor and isobenzan all $0.1 \%$.

Collembola: heptachlor $5 \%$, isobenzan $0.1 \%$.

At Timaru, the corresponding reductions in populations 47 weeks after treatment were:

Worms: fensulfothion and trichloronate $1 \%$.

Nematodes: diazinon $1 \%$, trichlorfon, fensulfothion and trichloronate $0.1 \%$.

Mites: fensulfothion and trichloronate $1 \%$.

C. zealandica: DDT, fensulfothion and trichloronate $1 \%$

Collembola: DDT 5\%, trichloronate $1 \%$, diazinon, trichlorfon and fensulfothion $0.1 \%$.

At West Melton the reductions in numbers 46 weeks after treatment were:

Nematodes and mites: fensulfothion and parathion $5 \%$.

Collembola: fensulfothion and parathion $1 \%$

Details of the six samples are given in Tables 1 to 3 . 
TABLE 1: NUMBERS OF SOIL ORGANISMS IN FOUR SAMPLES AT HALKETT

1 Week After Treatment

Worms Nematodes Mites C. zeal. Collembola

$\begin{array}{rlllll}\text { DDT: Totals } & 11 & 57 & 49 & 16 & 52 \\ \text { Stat. means and signif. } & 2.03 & 4.40 & 4.07 & 2.40 * * * & 4.17 \\ \text { dieldrin: Totals } & 6 & 55 & 36 & 25 & 23 \\ \text { Stat. means and signif. } & 1.57 & 4.33 & 3.47 * & 2.93 * & 2.80^{* *} \\ \text { heptachlor: Totals } & 8 & 53 & 28 & 43 & 41 \\ \text { Stat. means and signif. } & 1.80 & 4.23 & 3.03 * * & 3.80 & 3.73 \\ \text { isobenzan: Totals } & 0 & 41 & 1 & 15 & 0 \\ \text { Stat. means and signif. } & 0.7 * * * & 3.77^{*} & 0.88 * * * & 2.33 * * * & 0.7 * * * \\ \text { diazinon: Totals } & 6 & 34 & 7 & 15 & 21 \\ \text { Stat. means and signif. } & 1.57 & 3.43 * * & 1.70 * * * & 2.30 * * * & 2.77^{* *} \\ \text { trichlorfon: Totals } & 7 & 38 & 11 & 15 & 18 \\ \text { Stat. means and signif. } & 1.70 & 3.63 * & 2.03 * * * & 2.37 * * * & 2.50 * * \\ \text { phorate: Totals } & 0 & 5 & 0 & 42 & 1 \\ \text { Stat. means and signif. } & 0.7 * * * & 1.33 * * * & 0.7 * * * & 3.80 & 0.87 * * * \\ \text { carbaryl: Totals } & 2 & 57 & 55 & 19 & 23 \\ \text { Stat. means and signif. } & 1.03 * * & 4.40 & 4.33 & 2.63 * * & 2.83 * * \\ \text { Untreated: Totals } & 13 & 56 & 59 & 39 & 54 \\ \text { Stat. means } & 2.17 & 4.37 & 4.47 & 3.67 & 4.30 \\ \text { Diff. for signif. at 5\%* } & 0.63 & 0.59 & 0.82 & 0.59 & 0.95 \\ \quad 0.1 \% * * & 0.89 & 0.81 & 1.15 & 0.82 & 1.33 \\ \quad & 1.26 & 1.13 & 1.62 & 1.13 & 1.88\end{array}$

13 Weeks After Treatment

Worms Nematodes Mites C. zeal. Collembola

\begin{tabular}{|c|c|c|c|c|c|}
\hline DDT: Totals & 17 & 52 & 33 & 6 & 48 \\
\hline Stat. means and signif. & 2.47 & 4.20 & 3.40 & $1.50 * *$ & 4.07 \\
\hline dieldrin: Totals & 12 & 20 & 27 & 16 & 19 \\
\hline Stat. means and signif. & 2.10 & $2.70 * * *$ & 3.07 & $2.40 * *$ & $2.63 * *$ \\
\hline heptachlor: Totals & 10 & 23 & 17 & 0 & 19 \\
\hline Stat. means and signif. & 1.97 & $2.77 * * *$ & $2.47 * *$ & $0.70 * * *$ & $2.60 * *$ \\
\hline isobenzan: Totals & 0 & 41 & 2 & 0 & 1 \\
\hline Stat. means and signif. & $0.7 * * *$ & $3.70^{*}$ & $1.03 * * *$ & $0.70 * * *$ & $0.87 * * *$ \\
\hline diazinon: Totals & 16 & 28 & 28 & 4 & 26 \\
\hline Stat. means and signif. & 2.43 & $3.13 * * *$ & 3.10 & $1.33 * *$ & $3.00 *$ \\
\hline trichlorfon: Totals & 17 & 31 & 29 & 1 & 23 \\
\hline Stat. means and signif. & 2.47 & $3.27 * * *$ & 3.13 & $0.87 * * *$ & $2.77 * *$ \\
\hline phorate: Totals & 14 & 16 & 11 & 2 & 3 \\
\hline Stat. means and signif. & 2.30 & $2.40 * * *$ & $2.03 * * *$ & $1.03 * * *$ & $1.20 * * *$ \\
\hline carbaryl: Totals & 12 & 62 & 24 & 8 & 27 \\
\hline Stat. means and signif. & 2.13 & 4.57 & $2.90^{*}$ & $1.80^{* *}$ & $3.07^{*}$ \\
\hline Untreated: Totals & 16 & 64 & 36 & 30 & 46 \\
\hline Stat. means & 2.43 & 4.63 & 3.50 & 3.20 & 3.93 \\
\hline Diff. for signif. at $5 \% *$ & 0.48 & 0.68 & 0.60 & 0.71 & 0.76 \\
\hline $1 \% * *$ & 0.67 & 0.93 & 0.83 & 1.04 & 1.07 \\
\hline $0.1 \% * * *$ & 0.92 & 1.28 & 1.15 & 1.56 & 1.52 \\
\hline
\end{tabular}


52 Weeks After Treatment

Worms Nematodes Mites C. zeal. Collembou

$\begin{array}{rlllll}\text { DDT: Totals } & 13 & 66 & 60 & 2 & 59 \\ \text { Stat. means and signif. } & 2.20 & 4.63 & 4.50 & 1.0^{*} & 4.47 \\ \text { dieldrin: Totals } & 11 & 37 & 49 & 2 & 48 \\ \text { Stat. means and signif. } & 2.03 & 3.53^{* * *} & 4.07 * & 1.03^{*} & 4.03 \\ \text { heptachlor: Totals } & 12 & 24 & 15 & 1 & 26 \\ \text { Stat. means and signif. } & 2.13 & 2.90^{* * *} & 2.37^{* * *} & 0.87^{*} & 2.97^{* *} \\ \text { isobenzan: Totals } & 0 & 49 & 1 & 0 & 0 \\ \text { Stat. means and signif. } & 0.70^{* * *} & 4.10^{* *} & 0.88^{* * *} & 0.70^{*} & 0.70^{* * *} \\ \text { diazinon: Totals } & 16 & 70 & 55 & 9 & 55 \\ \text { Stat. means and signif. } & 2.47 & 4.83 & 4.30 & 1.73 & 4.30 \\ \text { trichlorfon: Totals } & 18 & 68 & 61 & 12 & 61 \\ \text { Stat. means and signif. } & 2.53 & 4.77 & 4.57 & 2.10 & 4.57 \\ \text { phorate: Totals } & 15 & 75 & 72 & 14 & 51 \\ \text { Stat. means and signif. } & 2.37 & 5.03 & 4.90 & 2.30 & 4.20 \\ \text { carbaryl: Totals } & 15 & 78 & 71 & 17 & 40 \\ \text { Stat. means and signif. } & 2.37 & 5.17 & 4.87 & 2.43 & 3.73 \\ \text { Untreated: Totals } & 14 & 73 & 62 & 10 & 53 \\ \text { Stat. means } & 2.27 & 5.00 & 4.57 & 2.10 & 4.23 \\ \text { Diff. for signif. at 5\%* } & 0.41 & 0.52 & 0.47 & 1.07 & 0.69 \\ 1 \% * * & 0.57 & 0.71 & 0.65 & 1.56 & 0.96 \\ \quad 0.1 \% * * * & 0.79 & 0.98 & 0.91 & 2.34 & 1.31\end{array}$

104 Weeks After Treatment

Worms Nematodes Mites C. zeal. Collembola

$\begin{array}{rlllll}\text { DDT: Totals } & 23 & 64 & 56 & 1 & 38 \\ \text { Stat. means and signif. } & 2.83 & 4.63 & 4.37 & 0.87^{* * *} & 3.63 \\ \text { dieldrin: Totals } & 16 & 57 & 48 & 1 & 33 \\ \text { Stat. means and signif. } & 2.40 & 4.47 & 4.03 & 0.87^{* * *} & 3.33 \\ \text { heptachlor: Totals } & 16 & 43 & 36 & 0 & 24 \\ \text { Stat. means and signif. } & 2.40 & 3.83 & 3.53 * * & 0.70^{* * *} & 2.90^{*} \\ \text { isobenzan: Totals } & 3 & 54 & 0 & 0 & 2 \\ \text { Stat. means and signif. } & 0.70^{* * *} & 4.30 & 0.70^{* * *} & 0.70^{* * *} & 1.03^{* * *} \\ \text { diazinon: Totals } & 22 & 59 & 63 & 16 & 45 \\ \text { Stat. means and signif. } & 2.80 & 4.47 & 4.60 & 2.47 & 3.93 \\ \text { trichlorfon: Totals } & 19 & 56 & 65 & 19 & 41 \\ \text { Stat. means and signif. } & 2.60 & 4.37 & 4.67 & 2.63 & 3.73 \\ \text { phorate: Totals } & 19 & 60 & 74 & 15 & 40 \\ \text { Stat. means and signif. } & 2.63 & 4.50 & 4.97 & 2.46 & 3.70 \\ \text { carbaryl: Totals } & 21 & 52 & 51 & 14 & 39 \\ \text { Stat. means and signif. } & 2.70 & 3.20 & 4.13 & 2.30 & 3.67 \\ \text { Untreated: Totals } & 20 & 56 & 59 & 19 & 41 \\ \text { Stat. means } & 2.63 & 4.37 & 4.47 & 2.60 & 3.77 \\ \text { Diff. for signif. at 5\%** } & 0.60 & - & 0.52 & 0.25 & 0.52 \\ 1 \% * * & 0.84 & - & 0.72 & 0.36 & 0.72 \\ 1 \% .1 \% * * & 1.15 & - & 1.01 & 0.54 & 0.98\end{array}$

271 

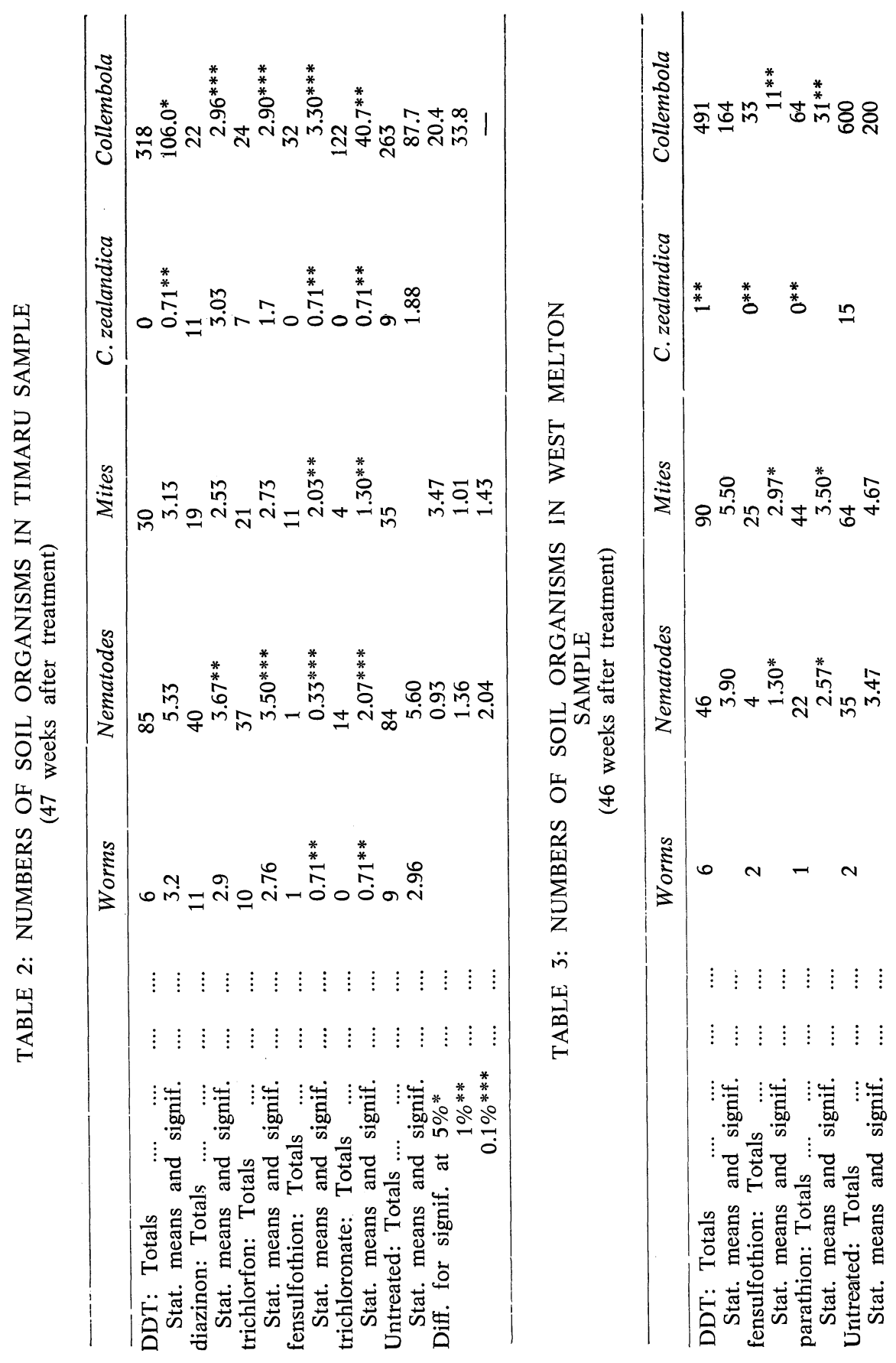


\section{GENERAL DISCUSSION}

Research workers on effects of insecticides on soil organisms are not yet able to place a definite value on the exact place played in the soil fertility cycle by any individual group in the above tables, and some members are definitely harmful if populations rise too high, so insecticide usage should aim at a balance which reduces damage to a practical level without upsetting desirable soil structure and fertility. It is definite from earlier Canterbury work (Kelsey and Arlidge, 1967) that at Halkett the loss of nearly all members of seven soil faunal groups - including the 5 recorded here - upset soil structure to such an extent that nearly $90 \%$ of root hairs were developed in a plant debris mat above soil ievel, whereas in untreated soil over $99 \%$ were within the soil itself, and the capacity of soil to absorb and retain water was reduced for a period of $31 / 2$ years. Isobenzan - the chemical in question - cannot be used, therefore, on soils where food production for any purpose is carried out, even though it is possible that cther soil types would not give the same responses to its use.

From the tables it can be seen that at Halkett (apart from isobenzan which had significantly lower populations of all 5 groups of organisms for the 2-year period), heptachlor reduced numbers of nematodes for one year, and mites, grass grubs and collembola for the 2 years, while dieldrin. affected nematodes and mites for 1 year and grass grubs for two years. Though effects of phorate and carbaryl on worms were severe at one week, populations had recovered on the small plots at 13 weeks. The three organophosphates, diazinon, trichlorfon and phorate, still had significantly lower numbers of nematodes, grass grubs and collembola at 13 weeks, but neither the organophosphates nor the carbamate had any effects on any of the 5 groups at 52 and 104 weeks. Carbaryl effects persisted for 13 weeks against mites, grass grubs and collembola, and DDT affected only grass grubs at any of the four counts. At Timaru, fensulfothion and trichloronate affected populations of all 5 groups for the 47 weeks of test, diazinon and trichlorfon affected nematodes and collembola and DDT lowered populations of grass grubs and collembola significantly. At West Melton, fensulfothion and parathion reduced numbers of nematodes, mites, grass grubs and collembola, and DDT affected grass grub numbers.

None of the listed insecticides has visibly affected soil structure at any of the 3 sites as did isobenzan at Halkett, even though some of them (heptachlor, ciazinon, trichlorfon and phorate) were observed over the same period of $3 \frac{1}{2}$ years reported on previously. However, there may be other factors than the 7 macrofaunal groups reported on from Canterbury, that could contribute to upsets in soil structure if adversely affected by insecticides. In this connection it is relevant to record data presented by I. D. Blair and B. N. Clayton of Lincoln College (pers. comm.) who reported that soil from Halkett treated 104 weeks earlier with DDT, diazinon and trichlorfon showed no significant differences in counts of clover nodulation between treated and untreated soil. However, with nitrifying bacteria, the counts in two replicates treated with diazinon two years previously represented reductions of 57 and $58 \%$ when compared with controls. Just how serious the effect is on nitrifying bacteria is open to doubt, because nitrogen available to plants can be applied readily in the form of urea, etc.

Though there have been no visible effects from usage of chemicals other than isobenzan, the fact that some of them do significantly reduce populations of the above faunal groups must be watched closely, and it is recommended that more detailed investigations should be a definite phase in chemical testing before general farm application is advocated. The counts 
above involve only one application, and the effects of many of the insecticides in the organophosphate group are likely to be serious if annual applications to pasture or crops become necessary - as they almost certainly will - for such insects as porina (Wiseana spp.), Argentine stem weevil (Hyperodes bonariensis), and clover case-bearer (Coleophora spp.). of the insecticides tested above, DDT is the obvious choice when effectiveness against insect pasture pests, and non-effectiveness against other soilinhabiting organisms are considered. The other materials affect a much wider range of species and many would have to be applied to the same paddocks annually. However, DDT may present problems also where nitrifying bacteria are important because some research workers have reported that DDD (a breakdown product of DDT) can have serious effects in reducing populations of at least one species of nitrifying bacteria (Garretson and van Clemente, 1968), though other workers had found no effects on nitrogen fixation, ammonification and nitrification or oxidation of sulphur to sulphide organisms (Jones, 1956).

The most important point illustrated in this paper is that the worldwide trend to replace long-residue chemicals (such as DDT and lindane) by those which have a short chemical life (most of the organophosphates being used), is based on insufficient scientific data. In addition it is backed (1) by nebulous fears that DDT, etc., may have some as yet undiscovered effects on humans; (2) by the 25 or so over-fed, over-producing countries effects on heans of avoiding competition on their own markets; (3) by countries like New Zealand which must keep produce free of residues in order to sell to these markets; (4) by commercial organizations which prefer to sell the short-life materials requiring annual use, rather than long-lasting chemicals applied less frequently.

The Director of the Medical Research Council's Toxicology Unit in Great Britain indicated (Barnes, 1967) that under-producing countries should not be governed by decisions made by the few over-producing countries who developed the Codex Alimentarius, when the alternative is starvation or malnutrition; they should be permitted to make their own choice of acceptmalnutrition; they should be perm residues of such relatively safe materials as DDT, lindane or malathion. What is needed is a campaign to place insectide usage in its correct and valuable place in the world, but this cannot be successful if possible side-effects are not investigated. The present attitude in New Zealand and elsewhere is that we must have an present attitude in New Zest problems; this is dangerous, and should be replaced by scientifically based facts from actual tests in this country. This paper presents a few preliminary facts indicating that, because some chemicals killed most members of five of the main groups of macrofaunal organisms, they are at least suspect as being candidates causing upsets in soil structure, since earlier Canterbury work showed that isobenzan which killed the same 5 groups and two others actually did destroy soil structure in circumstances as yet not fully understood.

\section{ACKNOWLEDGEMENTS}

Thanks are due to Miss E. Stevenson of Applied Mathematics Division, DSIR, and to Dr I. D. Blair, Head of the Microbiological Department, Lincoln College, for permission to use his data on insecticidal effects on nodulating and nitrifying bacteria.

\section{REFERENCES}

Barnes, J. M., 1967: Brit.Food J., May/June.

Garretson, A. L.; van Clemente, C. L., 1968: J. Econ. Entom., 61 (1).

Jones, L. W., 1956: Bull. 390, Utah State Agric. Exp. Stn.

Kelsey, J. M.; Arlidge, I. Z., 1967: N.Z. J. Agric. Res., 11 (2) : 245-60.

Meagher, J. W., 1963: J. Austr. Inst. Agric. Sci., 29 (1): 53. 